\title{
Confusion in a legal regime built on deception: the case of trade marks
}

\author{
Chris Dent* \\ Associate Professor, School of Law, Murdoch University, Australia
}

The law of trade marks is, now, reliant on the notion of 'confusion' between marks for the purposes of denying registration and of assessing infringement. Yet, this area of law is founded on the notion of deception - in the nineteenth century, a plaintiff had to show that the infringing mark would deceive consumers. This article takes a broad, sociolegal, approach to explore the factors that contributed to the introduction of 'confusion' into the legal discourse. These include the creation of the registration system itself; developments in the case law around the notion of 'deception', the breakdown of the rigidities in the law and the changes in how the system 'saw' the individual. This latter development involved the rise of utilitarianism, the acceptance of the 'internal life' of individuals and their possession of (potentially wrong) knowledge.

Keywords: trade marks, confusion, infringement, deception, consumers, socio-legal, utilitarianism

\section{INTRODUCTION}

There is no doubt that the concept of 'confusion' is, these days, a key aspect of the law of trade marks. For example, 'a trade mark shall not be registered if ... there exists a likelihood of confusion on the part of the public, which includes the likelihood of association with the earlier trade mark'. ${ }^{1}$ However, if the trade mark statutes of the mid- to late nineteenth century are considered, the 1875 and 1883 Trade Marks Acts both used only the phrase 'calculated to deceive'. ${ }^{2}$ Further, if the case law that preceded those Acts is examined, a body of decisions that necessarily focused on unregistered marks and the tort of passing off, ${ }^{3}$ then phrases such as 'fraudulent imitation' 4 and 'fraud upon the public'5 expressed the more moral basis of the legal enquiries of the time. The shift in the language happened at the same time that a firmer division was established between the law of trade marks

* This research forms part of a larger project funded by an Australian Research Council Linkage Grant (LP120100249). I'd like to thank Jason Bosland, Robert Burrell, Michael Handler, Steve Hedley, Paul Mitchell, Amanda Scardamaglia, and the anonymous referees, for their insightful comments and suggestions.

1. Trade Marks Act 1994 s 5(2).

2. $46 \& 47$ Vict. c. 57, s $72(2)$ and s 73 ; and $38 \& 39$ Vict. c. 91 , s 6.

3. It was not possible to register trade marks until the passing of the 1875 Act.

4. Knott v Morgan (1836) 2 Keen 213, 219.

5. Leather Cloth v American Leather [1865] 11 HLC 523, 542. 
and that of passing off. These days, the test of confusion is used in the former, whereas for the latter 'a claimant must show that the defendant's misrepresentation is deceptive'. ${ }^{6}$ The point of this paper is not to engage with the practical effect of the differences between the tests; instead it is to engage with the preceding issue: how is it that there is even a question to ask, that is, how is it that the term confusion entered into the law at all? In short, this research is founded on the observation that this shift in terminology has not been fully explored. ${ }^{7}$

The approach adopted here is to examine what may be seen as the "conditions of possibility' of the introduction of the term confusion. ${ }^{8}$ The argument here is that six factors may be seen to have supported its introduction into the trade mark discourse in the late nineteenth century. One is the creation of the registration system for trade marks and two reflect specific changes in the law more generally - the removal of the moral base of the test for 'deception' and a general trend in the nineteenth century away from the rigid legal categories that operated in the eighteenth century (including, but not limited to, shifts in the understanding, and limits, of contracts in contractual disputes). The other three aspects relevant to the use of 'confusion' relate to the broader legal trends of that era; namely the rise in the concept of the 'individual' that attaches to the utilitarian approach to governance, the increased understanding of the 'mentality' of both parties to court actions and consumers and the greater acceptance of individuals as possessing knowledge and being at risk of possessing erroneous knowledge. ${ }^{9}$ Again, none of these factors, in and of themselves, required that the term confusion enter into the legal lexicon; however, each of them is likely to have contributed, in a small way, to the word's initial use.

6. L Bently and B Sherman, Intellectual Property Law, 3rd edn (Oxford University Press, Oxford 2009), 756. The differences, now, between the tests in trade mark law and passing off will be discussed below.

7. While there is a connection between the words 'confusion' and 'deception', they are not synonyms. The Oxford English Dictionary defines 'confusion' as 'the confounding or mistaking of one for another; failure to distinguish' and 'deception' as 'the fact or condition of being deceived' (the most relevant definitions of the words have been selected for this comparison). Further, the New Zealand Court of Appeal has provided a useful contrast of definitions: the "meaning of "deceive" for present purposes may perhaps be regarded as equivalent to "mislead", with the implication of creating an incorrect belief or mental impression. Causing "confusion" may go no further than perplexing our mixing up the minds of the purchasing public': New Zealand Breweries v Heineken [1964] NZLR, 115, 142, Haslam, J.

8. The phrase 'conditions of possibility' is used in order to reduce inferences of causation between studied events: see, for example, A Hunt and G Wickham, Foucault and Law: Towards a Sociology of Law as Governance (Pluto Press, London 1994), 6-7. In other words, the factors considered in this article should not be seen to have, necessarily, caused the word 'confusion' to be used, however, the word's use may be seen to be contingent on the existence of the factors.

9. One area that will not be examined is the distinct common law and equity heritages of the nineteenth-century cases. Whereas the different courts did impact on the remedies available, it is not obvious to me how this aspect of trade mark history impacted on the introduction of the term 'confusion' to the discourse in the area. It may also be noted that, at least according to one commentator, the two courts 'often discussed the same precedents and spoke in the same terms regardless of the form of action' leading to 'an ambiguity regarding the real basis of trade mark law [that is] more semantic than substantive': M McKenna, 'The Normative Foundations of Trademark Law' (2007) 82 Notre Dame Law Review 1839, 1856. 


\section{USE OF 'CONFUSION' IN LATE-NINETEENTH-CENTURY DECISIONS AND AFTER}

Before the specific conditions of possibility are engaged with, there needs to be a consideration of whether the change, in fact, matters. One view could be that the shift was merely cosmetic - that the new word had no impact on the operation of the law. This section highlights how liability in the area of trade mark law, under the test of confusion, is different to liability based on deception. The first step is to explore the use of 'confusion' in the late nineteenth century and into the twentieth century. It is through an exploration of the test's use now that the contrast with the use of 'deception' in the law of passing off is best established.

\subsection{Eno v Dunn and other late-nineteenth-century decisions}

An important point in terms of the entry of the test of confusion is Lord Macnaghten's judgment in the 1890 decision of Eno v Dunn: ${ }^{10}$

[The use of the words 'fruit salt' by Dunn is] calculated, and I think designed, to create a confusion in the minds of those persons to whom Mr Dunn's advertisements are addressed, and to lead the ordinary run of such persons to suppose that this baking powder is in some way or other connected with Mr Eno's preparation. The object I think was ... to induce people to buy under an impression 'not founded in truth'. ${ }^{11}$

This is one of the first uses of the term 'confusion' in a trade mark decision and the first in a decision from the House of Lords - at least with respect to the potential for confusion between two products or marks. As it is an early use of the term, in this context it does not appear as if the Law Lord intended the word 'confusion' to mean something different to 'deception'; it is, nonetheless, important to note that he did choose to use that word. ${ }^{12}$

The use of the term 'confusion' in Eno v Dunn did not appear to be noted immediately. The first edition of Kerly's Law of Trade Marks, for example, still used the decision as a citation for the test of deception ${ }^{13}$ and Lord Macnaghten's judgment barely rated a mention in that treatise. The use of the term may not have been noteworthy because it had been used in three earlier trade mark decisions. First, in Leather Cloth Company v American Leather Cloth Company, Lord Kingsdown referred to the possibility of 'confusion' between the two companies, rather than the two marks. ${ }^{14}$ Second, Fry LJ, in 1886, made the abstract point that 'small marks are more likely

10. It should be noted that no other of the Law Lords deciding that case used the term 'confusion'. It has been claimed that Lord Watson used the word 'confusion' - see, for example, New Zealand Breweries v Heineken [1964] NZLR, 115, 132, North P. This claim is incorrect. 11. Eno v Dunn (1890) 15 App Cas 251, 263.

12. It would be possible to say that Lord Macnaghten's use of the term may simply be an example of his 'brilliant style and ... rare gift of humour': 'Preface' in A Selection of Lord Macnaghten's Judgments 1887-1912 (Butterworth \& Co, London 1951), iii. Such an assessment, however, obscures the fact that even his writing wit did not allow him to step outside the confines of what would be considered appropriate for a judgment in a given area of law.

13. Sir Duncan Mackenzie Kerly, Law of Trade-Marks, Trade-Name and Merchandise Marks (Sweet \& Maxwell, London 1894), 188.

14. [1865] 11 HLC 523, 540. 
to be confused than large marks'. ${ }^{15}$ Third, in another judgment in that year it was held that 'no instance has been shown where it is possible that anybody could be, I do not say deceived, but there could be any confusion or any misleading' about the use of the mark $;{ }^{16}$ again, this comment was made in the abstract as it was about the registration of the phrase 'Electric Velveteen' and did not involve the comparison of two marks. So, the use in Eno v Dunn appears to be the first decision in which the word confusion was used with respect to a comparison of two marks. ${ }^{17}$

The term was also being used in judgments in other areas of law. For example, in a context related, but not identical, to trade marks, it was held, in 1885, that the masthead of a paper 'may cause confusion and difficulty' given the name of an already published newspaper. ${ }^{18}$ There were also two decisions around the registration of names under the Companies Act 1862 that used the word 'confusion'. First, in 1878, it was held that given the number of banks' names that included the term 'Merchant', that no 'confusion has arisen through the similarity of name'. ${ }^{19}$ Second, in 1881, two judges used the word in their judgments in Hendriks v Montagu. ${ }^{20}$ Finally, in Day v Brownrigg, at first instance, Malins VC stated that to have two premises with the same name 'must lead to inconvenience and to confusion, and inconvenience is damage', ${ }^{21}$ the decision, however, was overturned on appeal and no members of the superior court used the term.

These references to 'confusion' in late-nineteenth-century decisions perhaps show a relative comfort with the term. There is no suggestion that this is an exhaustive list of the uses of the word; just an indication that it was not new to the discourse of the law, nor was it unique to the area of trade mark law. Such an acceptance of the term does not, in itself, explain why it came to be used as the basis for assessing the importance of differences between two marks. As a result, the term's introduction into the trade mark judgments is even more intriguing.

\section{2 'Cause to wonder' in twentieth-century trade mark decisions}

While Lord Macnaghten may not have intended to distinguish the terms 'confusion' and 'deception', the law relating to trade marks soon adopted the former term and developed it as a distinct concept. One of the phrasings of the test for confusion in modern trade mark law, drawn here from Australian jurisprudence, is whether potential purchasers 'would be caused to wonder whether it might not be the case that the

15. In re Lyndon's Trade Mark (1886) 3 RPC 102, 107.

16. In re Leaf's Trade Mark (1886) 3 RPC 289, 291, Bacon VC.

17. It may be noted that the term confusion entered the US trade mark lexicon before this time. It was part of the test for registration in that a new mark could not be one 'which so nearly resembles some other person's lawful trade-mark as to be likely to cause confusion or mistake in the mind of the public, or to deceive purchasers': Trade Mark Act 1881 s 3. The term, however, was in neither the Act of 1870 nor the Act of 1876 that had been ruled unconstitutional in the decision of Trade Mark Cases 100 US 82 (1879). The term 'confusion' entered the statutory tests around trade marks in the Trade Marks Act 1905 (UK) s 24.

18. Walter v Emmott (1885) 54 LJ Ch 1059, 1062, Cotton LJ.

19. Merchant Banking Company of Londonv verchants' Joint Stock Bank (1878) 9 Ch D 560, 566, Jessel MR.

20. (1881) 17 Ch D 638, 646, James LJ; 17 Ch D 638, 651, Cotton LJ.

21. (1878) 10 Ch D 294, 299. To avoid any confusion, it may be noted that this case did not involve the registration of a company name under the Companies Act 1862 but related to the names that residents gave to their houses. 
two products came from the same source'. ${ }^{22}$ Such an assessment is 'weaker' than the articulation in Eno v Dunn that the use of the impugned mark may 'lead the ordinary run of such persons to suppose that this baking powder is in some way or other connected with Mr Eno's preparation. The object I think was ... to induce people to buy under an impression "not founded in truth", ${ }^{23}$ The "cause to wonder' test does not require that the purchaser buy an item under a false impression. It is sufficient if 'an ordinary person [would] entertain a reasonable doubt' about the origin of the product. $^{24}$

Of course, the current UK test is based around any confusion felt by the 'average consumer'. ${ }^{25}$ A recent, again Australian, case offers an explanation of how consumers relate to trade marks:

It is a matter of common experience that people looking at a word often do not read it carefully. If they have in mind an earlier word they can mistakenly leap to the conclusion that the word they are looking at, if it has some similarity, is the one that they had in mind. ${ }^{26}$

The focus of this understanding, the 'mistaken leap', and that of the 'cause to wonder' is the 'effect of the similarity' 27 on consumers rather than the deceptive intent of the user of the impugned mark. The individual, and not the actions of the defendant, has moved to the centre of the analysis. This is not a criticism of the current approach, just an observation of a key change from the jurisprudence of the nineteenth century.

\subsection{Deception in passing off decisions}

Deception, on the other hand, was the basis of passing off actions in the early nineteenth century and remains the basis of the passing off actions in the twenty-first century. Decisions from the earlier period, of course, did not fully distinguish between trade mark disputes and those relating to passing off as there was no trade mark registration system at the time. An example of this lack of distinction is the case of Knott $v$ Morgan - an action that involved signs on buses. ${ }^{28}$ In terms of whether it should be considered a 'trade mark' or a 'passing off' decision, Wadlow refers to it as an 'early case' in his text on passing off; ${ }^{29}$ while nineteenth-century commentators referred to the case in trade mark treatises. ${ }^{30}$

More broadly, such decisions in the early nineteenth century focused on proof of actual deceit. This, unsurprisingly, was, in part, the result of the then still existing

22. Murray Goulburn Co-operative v NSW Dairy Corporation (1990) 24 FCR 370, 375.

23. Eno v Dunn (1890) 15 App Cas 251, 263.

24. Southern Cross Refrigerating v Toowoomba Foundry (1954) 91 CLR 592, 595.

25. See, for example, Sabel v Puma [1997] ECR I-6191.

26. Protiviti Inc v Probiti Pty Ltd [2005] FCA 1114, [22].

27. Shell Company v Esso Standard Oil (1963) 109 CLR 407, 416.

28. (1836) 2 Keen 213.

29. C Wadlow, The Law of Passing-Off: Unfair Competition by Misrepresentation, 4th edn (Sweet \& Maxwell, London 2011), 758.

30. See, for example, E Lloyd, The Law of Trade Marks with Some Account of its History and Development, 2nd edn (n.p., London 1865), 71; F Upton, A Treatise on the Law of Trade Marks (Weare C. Little, Albany 1860), 94; and C Drewry, The Law of Trade Marks (Knight and Co., London 1878), 9. 
forms of action. Ricketson highlights several decisions that indicate that the tort, being a 'special form of deceit', was limited to 'cases where fraud or intention to deceive was proved'. ${ }^{31}$ Those cases were Hogg $v$ Kirby, ${ }^{32}$ Canham $v$ Jones, ${ }^{33}$ Sykes v Sykes, ${ }^{34}$ Knott v Morgan, ${ }^{35}$ Crawshay v Thompson ${ }^{36}$ and Lord Byron $v$ Johnston. ${ }^{37}$ Examples of the relevant statements from these decisions include 'fraud upon the public'; ${ }^{38}$ 'a fraudulent attempt by one man to invade another's property' 39 'whether the defendant fraudulently imitated the title and insignia of the plaintiffs' $;{ }^{40}$ and 'fraud must be made out by proof of an intention existing in the mind of the party, that the iron should pass as the iron of plaintiff'. ${ }^{41}$ The emphasis, therefore, was, then, very much on the fraudulent activities of the defendant.

An action for passing off, today, requires that the plaintiff show a number of things key here is that the defendant made a misrepresentation about her or his goods or services. ${ }^{42}$ Judicial discussion of this aspect of the test considers the (arguably) different concepts of 'deception', 'confusion' and 'mere confusion'. ${ }^{43}$ Decisions such as Saville Perfumery $v$ June Perfect hold that, for a plaintiff to succeed in passing off, she or he must establish that 'ordinary consumers are deceived'. ${ }^{44}$ A more recent reference holds that passing off protects against the 'deceptive use of names, descriptive terms or other indicia to persuade purchasers or customers to believe that goods or services have an association, quality or endorsement which belongs or would belong to goods or services of, or associated with, another'. ${ }^{45}$ Finally, it has been stated that 'it is the likelihood of deception among consumers and of damage to reputation that are the critical requirements to establish a case of passing off' ${ }^{46}$ The focus of the test now, therefore, is unsurprisingly, again, on the impact of the behaviour on the consumers rather than on the deceptive actions of the defendant.

Further, the discussion of deception and misrepresentation in passing off cases means the test does not apply to the simple 'cause to wonder' instances that are protected in the

31. S Ricketson, 'Dilution and Confusion: The Bases of Trade Mark Infringement or the New Australian Trade Marks Anti-dilution Law 1999', in C Rickett and G Austin (eds) International Intellectual Property and the Common Law World (Hart, Oxford 2000), 129.

32. (1803) 8 Ves 215.

33. (1813) $2 \mathrm{~V} \& \mathrm{~B} 218$.

34. (1824) 3 B \& C 541.

35. (1836) 2 Keen 213.

36. (1842) 4 Man \& G 357.

37. (1816) 2 Mer 29.

38. Hogg $v$ Kirby (1803) 8 Ves 215, 226.

39. Canham v Jones (1813) 2 V \& B 218, 221.

40. Knott v Morgan (1836) 2 Keen 213, 219.

41. Crawshay $v$ Thompson (1842) 4 Man \& G 357, 377.

42. The test for passing off is not straightforward. As Gummow $\mathbf{J}$ has noted, the 'law of passing off contains sufficient nooks and crannies to make it difficult to formulate any satisfactory definition in short form': ConAgra Inc v McCain (1992) 33 FCR 302, 357.

43. The Privy Council, in Cadbury Schweppes v Pub Squash (1980) 32 ALR 387, asks 'Does confusion or deception ... amount to a passing off?' - seemingly differentiating between the two. Further, Phones $4 U$ [2006] EWCA Civ 44 offers a discussion of the difference between 'deception' and 'confusion'.

44. (1941) 58 RPC 147, 176. This case did involve a registered trade mark; however, an action for passing off was also run on the same facts.

45. Moorgate Tobacco v Phillip Morris (1984) 156 CLR 414, 445.

46. ConAgra v McCain Foods (1992) 23 IPR 193, 234. 
current (Australian) trade mark law. ${ }^{47}$ That is, according to commentators, for a passing off action to be successful, 'it is not enough for the public simply to be confused about whether it is getting the claimant's or the defendant's goods' ${ }^{48}$ Burrell and Handler have also noted that the 'dichotomy between confusion and deception ... is much more complex than it initially appears' ${ }^{49}$ One approach to untangling this complexity is to explore the manner in which the term confusion entered the trade mark discourse. The balance of this article, then, considers a number of features of nineteenth-century law and society that may be understood to have contributed to the introduction of the word into the jurisprudence.

\section{LEGAL DEVELOPMENTS OF THE NINETEENTH CENTURY}

It is not unusual to see the nineteenth century as a time of significant legal change. In other areas of intellectual property, there were major reforms to the patent law and design law; ${ }^{50}$ and, of course, there were the Paris and Berne conventions. It is less common, however, to explore the processes of change. This section highlights three aspects of the application of law that supported the introduction of the term confusion into trade mark law. They are: the shift away from the 'moral' dimension of deception; the introduction of the trade mark registration system; and a breakdown in the rigidities that were a feature of the early nineteenth century.

Methodologically speaking, this research is based on the understanding that the judges, particularly the appellate level judges, who hear cases within a particular area of law, are not limited to that area of law when deciding on the outcome. ${ }^{51}$ That is, it is the cross-fertilization of ideas that may be seen to facilitate change in the law. It is, therefore, across a range of sub-disciplines that evidence will be gathered to demonstrate the shifts in judicial thinking necessary for the notion of 'confusion' to be used where it never had been before.

\section{1 'Morality-free' deception}

In the nineteenth century, the concept of 'deception' was central to the regulation of commercial life. It was the basis of actions including those which would now be seen as contract (or assumpsit) and, as noted above, both the infringement of unregistered trade marks and passing off. By the end of the century, however, to establish

47. This contrast is clearest when the phrase 'cause to wonder' is considered in relation to the phrase the 'deceptive use of names ... to persuade purchasers' from Moorgate Tobacco (n 45; emphasis added).

48. W Cornish, D Llewelyn and T Aplin, Intellectual Property: Patents, Copyright, Trade Marks and Allied Rights, 7th edn (Sweet \& Maxwell, London 2010), 666.

49. R Burrell and M Handler, Australian Trade Mark Law (Oxford University Press, South Melbourne 2010), 406.

50. The reforming legislation included the Patent Law Amendment Act 15 \& 16 Vict. c. 83 (1852), the Designs Registration Act (1839), and the 1883 Act, already referred to, that amended the law of patents, designs and trade marks.

51. This is most evident when judges decide cases prima impressionis; for example, in the case of Vaughan $v$ Menlove, the judges discussed precedents from the area of bailment when deciding a question of negligence: (1837) 3 Bing (NC) 468, 474, Tindal CJ. For a discussion of this practice, see R Cross and JW Harris, Precedent in English Law, 4th edn (Clarendon Press, Oxford 1991), 200ff. 
deception did not require that the 'deceiver' be shown to be morally at fault. 'To cause confusion' may be a wrong but it may not have the moral basis that 'to deceive' originally had. It is likely that, should a strong moral aspect of deception have been retained until 1890, Lord Macnaghten would not have used the term 'confusion' in Eno v Dunn.

Admittedly, it is not clear at what point the courts did stop equating deception with 'moral obliquity'. 52 There is, of course, the ninth commandment 'thou shalt not bear false witness against thy neighbour' which indicated that lying was a $\sin .{ }^{53}$ There are also biblical warnings against fraud in commerce, in particular with respect to the falsification of weights and measures:

Thou shalt not have in thy bag divers weights, a great and a small. Thou shalt not have in thine house divers measures, a great and a small. But thou shalt have a perfect and a just weight, a perfect and just measure shalt thou have: that thy days may be lengthened in the land which the Lord thy God giveth thee. ${ }^{54}$

There were also statements in early decades of the nineteenth century that referred to deliberate acts of deception. ${ }^{55}$ For example, fraud could be in the form of 'a false representation, or in using means to conceal some defect'. ${ }^{56}$ More specifically, Lord Ellenborough stated:

Show me that the defendant entered into a conspiracy to cheat the plaintiff in this transaction, and perhaps you may rescind the contract entirely on account of the gross fraud committed by one of the contracting parties. But unless the contract be rescinded, this action cannot be maintained. ${ }^{57}$

Further, in an 1842 trade mark decision in Common Pleas, it was held that 'an intention to deceive is a necessary ingredient in this case'. ${ }^{58}$ On the other hand, in 1832, one lawyer was arguing the fact (rather than it being accepted as the law) before the King's Bench, after obtaining a rule nisi, that it was 'not necessary to prove that the false representation was made from a corrupt motive of gain to the defendant, or a wicked motive of injury to the plaintiff'. ${ }^{59}$

What can be said is that, during the mid- to late nineteenth century, the courts did highlight the separation of the moral from acts of deception. ${ }^{60}$ This is evident in two

52. Angus v Clifford [1891] 2 Ch 449, 471, Bowen LJ.

53. Exodus 20: 16, King James Version.

54. Deuteronomy 25: 13-15. It has been suggested that this passage hints at the use of the 'death penalty' for those who transgress its dictate: D Wood, Medieval Economic Thought (Cambridge University Press, Cambridge 2002), 98. The same author suggests, nonetheless, that the crime was 'common in medieval England': ibid. It may be further noted that the Merchandise Marks Act 1862 also included provisions for offences associated with the false labelling of products with respect to their 'number, quantity, measure or weight': ss 7,8 .

55. In terms of the relevance of medieval thought, there were some nineteenth-century cases involving the sale of goods that did look back to the thirteenth-century statutes in order to justify a decision. See, for example, Burnby v Bollett (1847) 16 M \& W 644, 654; 153 ER 1348, 1352.

56. Schneider v Heath (1813) 3 Camp 506, 508, Mansfield CJ.

57. Emanuel v Dale (1812) 3 Camp 299, 299, Lord Ellenborough.

58. Crawshay $v$ Thompson (1842) 4 Man \& G 357, 377, Coltman J.

59. Polhill $v$ Walter (1832) 3 B \& Ad 114, 123, Lord Tenterden CJ.

60. One aspect of this would have been differences between the Courts of the Common Law and those of Equity. It is not necessary, here, to go into the different requirements of actions in each jurisdiction on the basis that the use of confusion in trade mark law came after the fusing of the Courts in the 1870s. 
ways. The first may be seen in the quote from Eno $v$ Dunn in section 2 above: the use of the name was 'calculated, and I think designed, to create a confusion ...'. Lord Macnaghten was implicitly drawing a distinction between the term 'calculated' and the term 'designed'. ${ }^{61}$ The distinction was based on the assessment that a use of a mark could be 'calculated' to deceive without the user of the mark ever having the intention to deceive. ${ }^{62}$ This, at least, is a separation of the actor from the action in the early nineteenth century, there was only the matching of the action with the form of action; the distinction alluded to by Lord Macnaghten indicates that the two categories could be (but did not have to be) viewed as separate considerations in legal reasoning. In other words, the act could be seen as immoral without the actor also being immoral.

The distinction between 'calculated' and 'designed' is commonplace in current understandings of trade mark law but was not always thus. Eno v Dunn was not the first case to adopt this approach. A similar articulation may be found in the decision of Lee v Haley: 'I say that this was calculated, and I believe intended, to induce persons to believe that the business which the defendant carried on was the plaintiff's business'. ${ }^{63}$ The judges, in these statements, were articulating a difference between a finding, in law, that the actions amounted to an intention to deceive and the defendants actually having such an intention. ${ }^{64}$ That is, a legal finding of an intention may not, in fact, require that the defendant have an immoral intention. ${ }^{65}$

The second way in which the courts highlighted the separation of the moral from acts of deception is seen in the more explicit statements saying that deception did not require a moral failing. There are two forms in which such statements could be made. The first relates to the distinction drawn between 'moral fraud' and 'fraud in law'. Admittedly, the use of the term 'distinction' here is problematic as, in some cases, the judges highlight the two concepts and then do not fully separate them. For example, one judge said "we often talk of legal fraud, perhaps irregularly and improperly, as distinguished from moral fraud'. ${ }^{66}$ Earlier, Baron Parke said, 'I think it is essential that there should be moral fraud, and indeed all cases shew that it is, though the word legal fraud is

61. Cornish notes that the "phrase "calculated to deceive" had been used in passing off decisions ... in the sense of "fit" or "adapted" to mislead. It referred only to the effect of the action and not to the intention of the defendant': W Cornish, 'Industrial Property: Trade Marks and Unfair Competition', in W Cornish et al., The Oxford History of the Laws of England, Volume 12: 1820-1914 Fields of Development (Oxford University Press, Oxford 2010), 1003 n 84.

62. At first blush, it could be argued that the term 'calculated' had a different meaning in the nineteenth century. To counter this is a statement from the courts themselves: 'It is the duty of the court, in administering the law, to lay down rules calculated to prevent fraud' (Jones $v$ Bright (1829) 5 Bing 533, 542, Best CJ) - here it seems the judge is using the word 'calculated' to mean 'intended'.

63. (1869) LR 5 Ch App 155, 162, Giffard LJ.

64. Early instances include statements such as the courts 'have determined that if a man fraudulently and with intention to deceive makes a representation ... an action arises ex delicto': (1803) Tapp v Lee 3 Bos \& Pul 367, 370. Examples like this may, however, be interpreted as judges repeating themselves for effect.

65. Further, one judge went as far as to hold that it is 'no part of the duty of this court to enforce the observances of the dictates of morality': Batty $v$ Hill (1863) 1 H \& M 264, 268, Page Wood VC.

66. Singer Manufacturing $v$ Wilson [1876] 2 Ch D 434, 444, Jessel MR - no cases were cited to support the claim of 'we often talk of ...'. It may be noted that the Master of the Rolls was deciding the case at first instance and his judgment was included in the report of the appeal from that decision. None of the Court of Appeal judges raised a distinction between the two types of fraud. 
used' ${ }^{67}$ In a later case, however, the Baron did say that the 'cases shew a distinction between legal and moral fraud' ${ }^{68}$ In a more nuanced manner, Baron Parke did suggest that there were different 'degrees' of fraud - or more specifically, that there were examples of fraud that were of 'not so grave a character'. ${ }^{9}$ Further, Lord Abinger, also in Moens $v$ Heyworth, stated the 'fraud which vitiates a contract, and gives the party a right to recover, does not in all cases necessarily imply moral turpitude'. ${ }^{70}$ So, while the judges were loathe to fully distinguish moral fraud from legal fraud, they were content to refer to a potential difference and to accept that there were, at least, gradations of objectionable conduct. ${ }^{71}$

The second form of statements around the lack of need for a moral failing focuses on the judicial attention paid to the motives of those accused of fraud. To take an example, Lord Herschell said, in Derry $v$ Peek, that 'If fraud be proved, the motive of the person guilty of it is immaterial. It matters not that there was no intention to cheat or injure the person to whom the statement was made'. ${ }^{72}$ The Master of Rolls had also said there was 'no evidence against the bona fides of the applicant', yet the mark was still adjudged as being 'calculated to deceive'. ${ }^{73}$ Earlier, it was stated that it is 'impossible to look into the minds of the defendants or to detect their secret motives ${ }^{74}$ - in other words, there was no need for intent to be proved for a plaintiff to win. This is evidenced in the trade mark context in the early decision of Millington $v$ Fox: 'It does not appear to me that there was any fraudulent intention in the use of the marks. That circumstance, however, does not deprive the plaintiff of their right to the exclusive use of those names'. ${ }^{75}$

Note may also be made of the decision in Langridge $v$ Levy. ${ }^{76}$ The case involved the sale of a gun to the plaintiff that injured his son when the son fired it. To modern eyes, it has the hallmarks of an action in negligence. This, of course, was not available at the time. In the process of finding for the plaintiff, Baron Parke said:

The defendant has knowingly sold the gun to the father, for the purpose of being used by the plaintiff by loading and discharging it, and has knowingly made a false warranty that it might be safely done, in order to effect the sale; and the plaintiff, on the faith of that warranty, and believing it to be true, used the gun, and thereby sustained the damage which is the subject of this complaint. ... We, therefore think, that as there is fraud and damage, the result of that

67. Moens v Heyworth (1842) $10 \mathrm{M} \& \mathrm{~W} 147,157$.

68. Murray v Mann (1848) 2 Ex 538, 541.

69. Moens $v$ Heyworth (1842) $10 \mathrm{M} \& \mathrm{~W} 147,158$.

70. Moens $v$ Heyworth (1842) $10 \mathrm{M} \& \mathrm{~W} 147,155$.

71. Of note is Foster $v$ Charles (1830) 7 Bing 105. This decision was cited, in a later case, as the first in which the concept of 'legal fraud' was raised: Derry v Peek (1889) 14 App Cas 337, 365, Lord Herschell. In fact, the judges in Foster $v$ Charles were only surmising that the jury was trying to "draw the distinction between the sordid motive of personal advantage and the legal fraud which might be committed by a representation false within the knowledge of the speaker, although made without any view to his own advantage': (1830) 7 Bing 105, 107-8, Park J. Further, the concept had been raised in argument in an earlier Foster $v$ Charles decision but had been expressly rejected by Park J: (1830) 6 Bing 396, 403. One of the earliest instances of the phrase 'fraud in law' is in Freeman v Baker (1833) 5 B \& Ad 797, 805, Parke J.

72. Derry v Peek (1889) 14 App Cas 337, 374.

73. In re Rösing's Application (1885) 54 LJNS Ch 975, 975, Jessel MR.

74. Edelsten v Vick (1853) 11 Hare 78, 85, Page Wood VC.

75. (1838) 3 My \& Cr 338, 3521, Cottenham LC.

76. (1837) $2 \mathrm{M} \& \mathrm{~W} 519$. 
fraud, not from an act remote and consequential, but one contemplated by the defendant at the time as one of the results, the party guilty of the fraud is responsible to the party injured. ${ }^{77}$

There is no questioning of the actions of the defendant - it is not clear from the decisions whether the fault in the gun was the result of problems with the raw materials or faulty manufacture; the court, instead, found that fraud existed. It was enough that a 'misrepresentation' could be found and, once that was done, the plaintiff was entitled to the verdict. ${ }^{78}$

\subsection{Use of the registration system}

The second legal development to be discussed here does not reflect a change in the case law. It is the institution of a system of trade mark registration, under the 1875 Trade Marks Act, that also contributed to the use of the term 'confusion' in the law. ${ }^{79}$ The justification for this claim is that it was through the mechanics of registering a mark, and adjudicating disputes over such registration, that there was an increase in the need for one mark to be compared with another mark. A key point is that the use of the term confusion by Lord Macnaghten was in the context of the registration of a new mark (under s. 73 of the 1883 Act) - it was, therefore, not used in the context of a defendant company acting, allegedly, against the interests of a trade mark owner. Arguably, this had implications for the way in which Law Lords conceived of the (potential) harm; however, it is sufficient here to simply emphasize that the processes of registration impacted on the development of the law itself.

Two additional impacts of the registration system are the likely increase in the number of disputes that came before the courts and the (new) mental processes undertaken by the judges when adjudicating those disputes. ${ }^{80}$ The doctrinal nature of this article means that an empirical study of the number of trade mark disputes before and after the 1875 Act would be out of place. It is sufficient to note that the provisions in the Act that gave the Courts adjudicatory powers over the registration of marks ${ }^{81}$ are in addition to the capacity of trade mark owners to seek court action over the alleged infringement of their marks. It would seem, therefore, that it was likely that the additional powers would mean additional actions brought before the court. Four other points may be made around the potential for the increase in the role of judges in trade mark disputes. First, the ability of a trader to protect the mark, as soon as it is registered, did not

77. Langridge v Levy (1837) $2 \mathrm{M} \& \mathrm{~W} 519,531-2$, Parke B.

78. Here the term 'plaintiff' is used generically to denote the party that has suffered harm and 'defendant' is used to refer to the party that is accused of 'deceptive' or improper conduct. In a number of early cases, the action was commenced by the vendor to force payment in circumstances where the purchaser alleged deception. See, for example, Bluett v Osborne, in which the seller of a 'defective' bowsprit was not liable: (1816) 1 Stark 384.

79. Further, it is not clear that the role of the registration system as an ordering of knowledge in the trade regime has had the attention it deserves. One of the few attempts in this area, and one that does not have an historical bent, is R Burrell, 'Trade Mark Bureaucracies', in G Dinwoodie and M Janis, Trademark Law and Theory: A Handbook of Contemporary Research (Edward Elgar, Cheltenham 2008).

80. For a broader discussion of the effects of registration on the intellectual property system, see B Sherman and L Bently, The Making of Modern Intellectual Property Law (Cambridge University Press, Cambridge 1999), Ch. 9; for a history of registration in intellectual property, see C Dent, 'Registers of Artefacts of Creation - from the Late Medieval Period to the 19th Century' (2014) 3(2) Laws 239, doi:10.3390/laws3020239.

81. Trade Marks Act 1875 ss 5, 6 . 
require that the trader built a reputation over time before bringing an action. ${ }^{82}$ Second, the shift in the onus of proof from the plaintiff to the defendant ${ }^{83}$ may have meant that prospective plaintiffs were more likely to litigate as they no longer had to prove that they were 'entitled to the exclusive use of the mark' ${ }^{84}$ Third, it is possible that the mere fact of the passing of the Act may have increased awareness of the role of trade marks in commerce, which may, in turn, have increased the use of the system and, further, the number of disputes under the system. ${ }^{85}$ Finally, the new system enabled individuals to 'game' it:

Innumerable cases have come before me as Acting Commissioner where a proposed mark was rejected because it was too near an old mark. A fortnight afterwards there comes another application by the same man to register the same mark with a slight alteration. That is rejected. In another fortnight another attempt is made to register it with another slight variation, and continued attempts are thus made. ${ }^{86}$

This quote highlights the further shift in nineteenth-century trade mark practice from the outright duplication of signs of the plaintiff ${ }^{87}$ to the actions of defendants where they try to 'sail as close to the wind' as possible. Of course, such filings, in the end, were challenged in the courts. ${ }^{88}$ What is more important here, though, is that any increase in the number of disputes over the use of marks increases the opportunities to consider the visual relationship between different marks and the impact the marks may have had on the minds of consumers.

The cases that are reported, post-1875, evidence the processes undertaken by judges when adjudicating these disputes. In terms of the mechanics, the judges considered that the marks should be looked at as 'they will probably be used in the course of trade' ${ }^{89}$ Further, 'you must not try [the question] exclusively by your eyes. It is equally true to my mind that you must not try it exclusively by the evidence. You

82. See, for example, Hall v Barrows (1863) 4 De G J \& S 150; and Seixo v Provezende (1861) LR 1 Ch App 192. Even after the introduction of the registration system, the judges saw the question of infringement in terms of whether the defendant was 'using some mark which is calculated to pass off their goods as the goods of the plaintiff': Mitchell v Henry (1880) LR 14 Ch 181, 190, James LJ.

83. Trade Marks Act $1875 \mathrm{~s} 3$. Section 3 provided that the registration of a mark 'shall be prima facie evidence of [the owner's] exclusive use of such trade mark, and shall, after the expiration of five years from the date of such registration, be conclusive evidence of his right to the exclusive use of such trade mark'.

84. J Bryce, Trade Marks Registration Acts 1875 \& 1876 (William Maxwell \& Son, London 1877), 2. Of course, the fact that the onus shifted did not necessarily mean that plaintiffs were more likely to win. It is sufficient to suggest that they thought their chances were greater, which leads to more litigation, which, importantly for the purposes here, leads to more decisions by the courts about the use and appearance of trade marks.

85. It is also possible that the 1862 Merchandise Marks Act increased the level of interest in trade marks amongst UK industries. This may be supported by the comment of Lloyd that 'nearly one-fourth of the cases reported [in the area of trade marks] have been decided within the last two years': above n 30, xi.

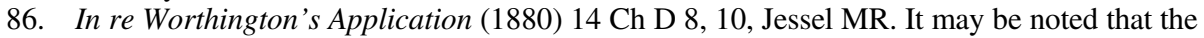
Master of the Rolls did not, in relaying his experience, impute any moral failing to the behaviour of such an applicant.

87. Such as in the case of Knott v Morgan referred to above, n 28 and the accompanying text. 88. The Master of the Rolls indicated that he notified the owner of the old mark of the new applications if the process went on too long: (1880) 14 Ch D 8, 10.

89. In re Christiansen's Trade Mark (1886) 3 RPC 54, 59, Lord Esher MR. 
must use both.... You must look upon it with your eyes and with your powers of thought and opinion' ${ }^{90}$

Examples of the 'powers of thought and opinion' of the judges include those decisions in which they considered the use of the mark in practice - rather than just comparing pristine versions of the mark. In one decision, the Master of the Rolls noted that a mark on cutlery was 'very liable to get more or less blurry' as the piece was used. ${ }^{91}$ In another decision it was considered how the colours of a mark would fade over time. ${ }^{92}$ In other words, the judges did not just do a simple side-by-side comparison when arriving at a decision. ${ }^{93}$ That said, the Commissioner, when first admitting a mark to the register, can only have his 'eyes' when assessing the similarity of a new mark to an old one.

In terms of their characterization of differences between marks, the Lord Chancellor noted that a mark is an 'imitation' if it can be shown that it was 'ambiguous and capable of being understood by different persons in different ways'. ${ }^{94}$ This is a more nuanced understanding than the yes/no test implicit in the question: was there 'such a resemblance of the plaintiff's mark as was calculated to impose on any ordinary person' ${ }^{95}$ Even the assessment of a registered mark as 'very nearly resembling' ${ }^{96}$ an older mark suggests a greater gradation of similarity than the earlier characterizations of the test. ${ }^{97}$ One characterization of difference, however, is not easily understood from a twenty-first century perspective: 'No general rule can be laid down as to what is or is not a mere colourable variation' ${ }^{98}$ It appears to still be a yes/no question; however, all the connotations of the word 'colourable' are not clear now. ${ }^{99}$

It may not, however, just be the passing of the 1875 Act that contributed to the changing understanding of the judges. The 1862 Merchandise Marks Act, with its standard for forging a trade mark as the rendering of a mark to 'resemble any genuine trade mark', ${ }^{100}$ is also likely to have contributed. There are cases decided after the passing of

90. (1886) 3 RPC 54, 60, Lord Esher MR.

91. In re Rösing's Application (1885) 54 LJNS Ch 975, 977.

92. In re Worthington's Application (1880) 14 Ch D 8, 14, James LJ.

93. As another example, see Seixo v Provezende (1861) LR 1 Ch App 192, 195, Cranworth LC.

94. Singer Manufacturing Company v Loog (1882) 8 App Cas 15, 17, Lord Selborne LC.

95. Crawshay v Thompson (1842) 4 Man \& G 357, 377, Coltman J. As a matter of pragmatism, it had to be a yes/no question because it was up to a jury to assess whether a fraud had taken place.

96. In re Rösing's Application (1885) 54 LJNS Ch 975, 976, Jessel MR.

97. Such a nuanced understanding is also evident in another assessment: 'the resemblances between the two are so great that, although there are differences which might be detected, yet those differences are not so obvious as to make the whole dissimilar. ... If the dissimilarity is so small, and the common features so numerous, that the two as a whole are similar, the dissimilarity goes for nothing': In re Christiansen's Trade Mark (1886) 3 RPC 54, 63, Lindley, J.

98. Leather Cloth Company v American Leather Cloth Company (1865) 11 HLC 523, 535, Lord Cranworth.

99. It may be noted that, even in the nineteenth century, the phrase was not precise. 'The words "colourable imitation" are words which appear to me not very happily chosen, and calculated to create some confusion': Dudgeon v Thompson (1877) LR 3 App Cas 34, 43-4, quoted in H Cunynghame, English Patent Practice (W. Clowes \& Son, London 1894), 292. It may be further noted that, in Canada at least, 'the charge of a colourable imitation ... must necessarily include a charge of fraud': Barsalou v Darling (1882) 9 SCR 677, 696.

100. Section 5. Poland noted that this section was 'very obscurely worded'; however, his discussion of the section did not touch on the degree of similarity between the forgery and genuine mark: H Poland, The Merchandise Marks Act 1862 with Notes (John Crockford, London 1862), 33-5. 
the Act, such as Hirst $v$ Denham, that hold that one mark 'very closely resembl[es]' another mark. ${ }^{101}$ Before the 1870 s, however, judges were less nuanced in their assessment of differences. In Collins Company $v$ Brown, the mark in question was simply a 'similar mark'; ${ }^{102}$ and in Edelsten v Edelsten, the Lord Chancellor asked whether the marks were 'substantially the same'. ${ }^{103}$ In short, an assessment of a mark being confusing is not one of either/or - confusion is a state of uncertainty rather than of truth or fraud. The use of confusion, as a test, by the judges, therefore, required that they moved away from the binary of deception evident in the early-nineteenth-century decisions. The first step in that process may have been the use of the word 'resemble' in the 1862 Act. And, of course, simply because the judges were interpreting new statutes, they were freed from the strict confines of the preceding cases - there were new provisions that did not match the older passing off actions and the processes of registration allowed new characterizations that did not map directly to the circumstances of one trade suing another over an action in the marketplace. After the three Acts, the judges seemed much more comfortable to assess differences between marks in a nuanced, rather than absolute, manner.

\subsection{Breakdown in the rigidities of law}

There is one final set of developments that may have played a role in the use of the concept of 'confusion'. Broadly speaking, these changes relate to the breakdown in the strict categories that defined the law in the early parts of the nineteenth century. Two of them need little discussion as they are well known. As summarized by one commentator, the Judicature Act of $1873^{104}$ 'not only abolished the ancient forms of actions but the ancient courts, and provided for one Supreme Court of Judicature ... providing so far as the statute could provide for the fusion of law and equity' ${ }^{105}$ It may be further noted that key aspects of the forms of action had already been abolished in the 1830s. ${ }^{106}$ Taken together, these reforms meant that the English 'law has ceased to be a scientific game which may be won or lost by playing some particular move'. ${ }^{107}$ In isolation, however, these changes may not have done much in terms of the language of the legal decisions but they are at least indicative of the shift away from historically defined categories.

The third shift away from rigidity in the law to be discussed here relates to judicial attitudes to the 'sanctity' ${ }^{108}$ of contracts as agreements between two parties ${ }^{109}$ - more

101. (1872) LR 14 Eq 542, 551. Bacon VC.

102. (1857) 3 K \& J 423, 428, Page Wood VC.

103. (1863) 1 De G J \& S 185, 199.

104. 36 \& 37 Vict., c. 66.

105. F Judson, 'A Modern View of the Law Reforms of Jeremy Bentham' (1910) 10 Columbia Law Review 41, 45.

106. Uniformity of Process Act 1832, 2 \& 3 Will IV, c. 39; and Real Property Limitation Act $1833,3 \& 4$ Will IV, c. 27 . As was noted above, the early passing off decisions were founded on the old action for deceit.

107. Justice Bowen, quoted in Judson, above n 105, 45.

108. '... contracts when entered into freely and voluntarily shall be held sacred and shall be enforced': Printing and Numerical Registering Company v Sampson (1875) LR 19 Eq 462, 465, Jessel MR.

109. A justification for the privileging of contracts was provided by Jessel MR: 'I have always thought, in those cases where the Court is satisfied of the bona fides of a transaction, and its entire freedom from the mischief which the established principle of law was intended to prevent, 
specifically, the changes in the extent of contractual relationships, loosely referred to as the notion of privity, over the course of the nineteenth century. ${ }^{110}$ To take an example, looking back to Langdridge v Levy, one of the reasons why negligence, as we now know it, did not govern liability two centuries ago is because judges resisted the notion that a supplier of a product or service could be held liable by someone outside the contract of purchase or service. In an 1865 decision, it was stated that 'I find no case where an action has been sustained by the master for consequential damage for an injury done to his servant, where the injury arose from the breach of a contract between the servant and the defendant'. ${ }^{11}$ To re-use a hackneyed phrase, they were concerned about opening the 'floodgates' of liability. ${ }^{112}$

That said, there were a number of cases in the first half of the century in which someone who was harmed by the provider of a service, yet did not pay for it, did succeed. For example:

The argument of the defendant proceeds on the supposition, that this case must be governed by the same rules as if the action were brought on a contract: this action, however, is neither brought on a contract nor founded on one: it is brought by a person who has sustained bodily injury, and by the only person who could sue for it. ${ }^{113}$

In other words, liability began to be seen to arise not from 'contract, but from a duty; it is perfectly unimportant by whom the reward is to be paid'. ${ }^{114}$ Further, as will be seen below, ${ }^{115}$ nineteenth-century judges also came up with a formulation of liability that is very similar to the infamous one of Donoghue $v$ Stevenson ${ }^{116}$ in the decision of George $v$ Skivington ${ }^{117}$ and, of course, there was Langridge $v$ Levy itself, ${ }^{118}$ discussed above, where a seller of guns was held liable for the harm suffered by the son of the purchaser.

So, in the middle of that century, there were apparently conflicting statements around the limitations that a lack of contractual relationship had on the apportionment of liability. ${ }^{119}$ No doubt, the differences may be explainable through a more nuanced

that the Court should lean on the side of fair dealing, and should not so apply the principle of law so as to make it comprise a case not within the mischief which it was intended to prevent without absolute necessity, the necessity being that of preserving the principle untouched for the guidance of mankind in their ordinary transactions': Albion Steel and Wire Company v Martin (1875) 1 Ch D 580, 584-5.

110. Atiyah notes that by 1870 the laissez-faire approach of the English judges had waned: P Atiyah, An Introduction to the Law of Contract, 5th edn (Clarendon Press, Oxford 1995), 15.

111. Alton v Midland Railway Company (1865) 19 CB(NS) 213, 237, Erle CJ.

112. As was noted in a mid-nineteenth-century decision: 'The contract in this case was made with the Postmaster-General alone; and the case is just the same as if he had come to the defendant and ordered a carriage, and handed it at once over to Atkinson. If we were to hold that the plaintiff could sue in such a case, there is no point at which such actions would stop. The only safe rule is to confine the right to recover to those who enter into the contract: if we go one stop beyond that, there is no reason why we should not go fifty': Winterbottom $v$ Wright (1842) 10 M \& W 109, 115-16, Alderson B.

113. Gladwell v Steggall (1839) 5 Bing (NC) 733, 736, Bosanquet J.

114. Marshall v York, Newcastle and Berwick Railway Company (1851) 11 CB 655, 663, Jervis CJ.

115. In section 4.2 .

116. [1932] AC 562.

117. (1869) LR 5 Ex 1.

118. (1837) 2 M \& W 519.

119. Atiyah notes that 'not all judges ... were enthusiastic adherents of freedom of contract': above $\mathrm{n} 110,9$. 
reading of the decisions and declarations that founded them; what is important here is that judges began to free themselves from the confines of a rigid understanding of the boundaries of contractual obligations. It may be that the decline in the importance of privity - the strict limiting of liability to parties to an agreement - enabled judges to see the impact of behaviour on others outside any specific agreement. This shift, when linked with the other more structural reforms of the nineteenth century, may be seen to have provided the space for the emergence of a new category - the utilitarian individual.

\section{HOW NINETEENTH-CENTURY LAW CAME TO SEE INDIVIDUALS}

Given the old forms of action, the category of the individual was not central to the understanding of the law in 1800. It is argued here, however, that it is a key condition of possibility for the introduction of confusion into the trade mark law. Three broad developments in the legal discourse help to flesh out this claim: the acceptance, in the law, of members of society as individuals with specific attributes; the acknowledgement of the 'internal' life of those individuals; and the understanding that individuals possess knowledge and that knowledge may be incorrect.

\subsection{Individuals as Utilitarian Individuals}

To acknowledge the importance of the utilitarian perspective to the development of intellectual property rights is not new. ${ }^{120}$ Sherman and Bently, for example, have noted that 'the language of classical jurisprudence was replaced by the language of political economy and utilitarianism'. ${ }^{121}$ This section considers the words of the legal treatise writers and the judges to emphasize the changing legal understandings of the individual. By way of providing context, utilitarianism is named for its understanding of the principle of utility. Beneath that principle - loosely described as the greatest good for the greatest number - lies three assumptions: (1) that there are individuals that can suffer pleasure or pain; (2) that in society there are different people who will be suffering different amounts of pleasure and pain; and (3) that the numbers of people may be known (at least in theory). ${ }^{122}$ For Bentham, seen as the 'father' of utilitarianism, "each individual always pursues what he believes to be his own happiness. The business of the legislator, therefore, is to produce harmony between public and private interests'. ${ }^{123}$

120. See, for example, W Landes and R Posner, 'Trademark Law: An Economic Perspective' (1987) 30 Journal of Law and Economics 265. It may be noted, however, that the approach of these authors would not be recognized by the early utilitarian writers such as Jeremy Bentham. 121. Above n 80, 176.

122. One commentator has noted that 'unlike some of his more recent disciples ... Bentham was fully aware of the complexities of assessing and estimating pleasures': F Rosen, Classical Utilitarianism from Hume to Mill (Routledge, London 2003), 179.

123. B Russell, History of Western Philosophy, 2nd edn (George Allen and Unwin, London 1961), 741. Bentham, famously, was not keen on the common law; 'Bentham criticised virtually every facet of common law jurisprudence for its general obscurity, inaccessibility and illogicality': M Davies, Asking the Law Question, 2nd edn (Lawbook Co, Sydney 2002), 60. As a result, he thought that change should be legislated. This does not mean that the judges did not incorporate some of the underlying understandings of utilitarianism into their judgments. 
Further, it may be noted that the 'law reformers, whether in or out of Parliament ... were all at bottom individualists'; ${ }^{24}$ it is unsurprising, then, that a key change in the operation of trade mark law may be linked to the individualism of utilitarianism.

In terms of the language used by the writers of trade mark treatises, there is little material on the Merchandise Marks Act 1862 that may be used to glean the underlying understandings of the authors. Poland, for example, simply echoes the preamble of the statute when he states:

For years past it has been felt that the legislature must sooner or later interfere for the purpose of preventing the forgery of trade marks and the false marking of merchandise, but until 1860 it does not appear that any active measures were taken for removing the evils which were admitted on all hands to exist. ${ }^{125}$

His use of the moral pejorative of 'evils' and his lack of reference to the position of the consumer is, however, noteworthy. ${ }^{126}$ Lloyd is clearer. In terms of the

exclusive right to a trade mark ... the existence of a natural right [must] be assumed, to account for these instances in which its violation has repeatedly been punished. ... Here the advantage to the public, supposed to be that of a peculiarly excellent commodity, is, as we all know, frequently small, often altogether illusory, while the privilege of the trader is in many respects considerable, and is without limit in point of duration. ${ }^{127}$

While Lloyd does speak of the natural rights of the owner of a trade mark, he, at least, acknowledges the potential for the individual consumer to benefit from the enforcement of the owner's rights.

The language in the treatises following the Trade Marks Act 1875 changes. According to Adams:

The first principle upon which the courts of law and equity have interfered for the protection of trade marks appears to be, that one man shall not be allowed to sell his goods as the goods of another. In the exercise of this jurisdiction by the courts, two other principles are necessarily involved: the prevention of fraud upon the public, and the protection of the property of the plaintiff. ${ }^{128}$

Here, the interests of the public are given a higher priority than in the works of either Poland or Lloyd. Sebastian goes further:

The protection of trade marks is beneficial to the public, since it enables them to buy, with confidence that they are getting what they require, at the same time it is beneficial to the manufacturer,

124. AV Dicey, Lectures on the Relation between Law and Public Opinion in England During the Nineteenth Century (Liberty Fund, Indianapolis 2008), 120-1.

125. Above n 100, 5.

126. The strength of feeling against infringement amongst some is evident in the words of a solicitor: 'The systematic frauds of this class both in this and other countries are so extensive that it is necessary that some strong check should be provided; and I believe that when it is understood that the practice will be regarded no longer as a venal offence, but as a crime punishable with imprisonment, it will be deemed too dangerous or too disgraceful to be used': A Ryland, 'The Registration of Trade Marks' (1861) 5 Solicitors' Journal and Reporter, 839, 841. 127. Above n 30, 2.

128. F Adams, A Treatise on the Law of Trade-Marks (Butterworths, London 1876), 11. Similarly, Drewry notes that Equity saw the infringement of a trade mark as a 'double fraud: fraud on the original framer of the trade mark, by injuring his trade and reputation; and fraud as against the public, by inducing them to buy the infringer's goods, believing them to be the goods of the originator of the trade mark': above n 30, xii. 
since it affords him the means of securing the benefit of the custom which he deserves and which is intended for him. ${ }^{129}$

It can be seen that Sebastian is raising the idea of a utilitarian mentality in consumers. He sees them as being capable of choosing and of having confidence in their choices. Similarly, Ludlow and Jenkyns highlight that trade marks function to 'inform the public' and that 'buyers may have found by experience that iron branded with a particular mark was specially free from brittleness, and the mark may have come to suggest this and no other conclusion'. ${ }^{130}$ Adams also highlights that a mark may be 'an assurance to the public that they are reaping the benefit of some person's superior skill, or the peculiar local advantages of some place'. ${ }^{131}$ Unsurprisingly, the commentators did not wax lyrical about the capacity of consumers to make decisions in their own interests; however, they did leave sufficient hints to indicate that the utilitarian mode of thinking was not anathema to the law of the time.

Further, the decisions of the courts may be examined in order to explore any suggestion of utilitarian traces in the law. The argument here is not that utilitarianism was the sole basis of understanding the function of trade marks - that is, this is not an attempt to add to the debate about the 'true' function of trade marks ${ }^{132}$ - but that some aspects of utilitarian thinking are evident in the words of the judges. The first aspect of the approach is the suggestion that trade mark law is there for the protection of the public; ${ }^{133}$ and the second is the acknowledgement that members of the public have minds that are capable of choice - this will be explored in the next section.

With respect to the first aspect, in Leather Cloth $v$ American Leather, Lord Kingsdown spoke of 'fraud upon the public'. ${ }^{134}$ A partial utilitarian interpretation of the Trade Marks Act 1883 was offered by the Lord Chancellor in the arguments for Eno v Dunn: 'Is not section 72 of the Act for the protection of traders and section 73 for the protection of the public?'135 In Civil Service Supply v Dean, a trade mark case, it was held that the 'rules of trade are made for the general public and for rational persons'. ${ }^{136}$ The public policy nature of other legislation is referred to in Cowley $v$ Mayor, Aldermen and Burgesses of the Borough of Sunderland where it was said that the purpose of the statute in question was 'for the benefit of the poor and more ignorant classes of the population'. ${ }^{137}$ While this statement is not from a trade mark case, it does demonstrate how the public benefit was a feature in the thinking of judges

129. L Boyd Sebastian, The Law of Trade Marks and Their Registration (Stevens and Sons, London 1878), 3-4.

130. H Ludlow and H Jenkyns, A Treatise on the Law of Trade-Marks and Trade-Names (William Maxwell \& Son, London 1877), 2. Interestingly, the authors cite Austin and the 'language of scientific jurisprudence' (ibid, 3), with Jeremy Bentham having been 'Austin's original mentor': R Cotterrell, The Politics of Jurisprudence (Butterworths, London 1989), 52.

131. Above n 128, 60.

132. For a coherent argument for the non-utilitarian approach, see McKenna, above n 9.

133. For example, in a case for the sale of meat, it was noted that 'any legal point which in the remotest degree bears upon the public health and the general safety of the community is deserving of the fullest consideration': Emmerton v Mathews (1862) 7 H \& N 586, 593-5, Pollock CB.

134. [1865] 11 HLC 523, 542. Lord Westbury, in the court below, however noted that 'imposition on the public, occasioned by one man selling his goods as the goods of another, cannot be the ground of private action or suit': Leather Cloth Co. v American Leather Co. 4 De G J \& S 137, 141. 135. 7 RPC 311, 313, Lord Halsbury. The arguments of the parties were not included in the other report of the decision.

136. (1879) 13 Ch D 512, 516, Malins VC.

137. (1861) $6 \mathrm{H} \& \mathrm{~N} 565,574$, Wilde B. 
more broadly. In less known trade mark cases, it was said 'the court does not protect the trade ... but the public', ${ }^{138}$ and 'as long as people compete in fair competition it is lawful'. ${ }^{139}$ The latter statement is one of the earliest conceptions of trade mark law in terms of what would now be seen as an economic perspective. Returning to Eno v Dunn, Lord Macnaghten used the phrase 'the innocent public'140 implicitly acknowledging them as the group that needs to be protected from fraudulent traders.

\subsection{Individuals as having an 'internal' life}

Another significant, yet gradual, shift evident in the legal discourse of the time was the introduction of the 'mentality' of parties in the adjudication of disputes. ${ }^{141}$ It is, now, a well-established judicial practice to consider the 'reasonable person' - perhaps best known from the 'duty of care' established in Donoghue $v$ Stevenson. ${ }^{142}$ This approach, however, was a creation of the nineteenth-century judiciary. ${ }^{143}$ The argument here is that, without a general trend towards a more nuanced view of, initially, the defendant, it is unlikely that the nuanced understanding of the population of consumers would have been adopted. In other words, the argument is that, for a judge to consider that a consumer could be 'confused', the judge must have a capacity to assess the internal mental processes of the public. Such a capacity requires that the judges have the capacity to assess the mental processes of the parties who appear before them - as it is unlikely that the conception of the abstract consumer could be based on anything other than an extension of the assessment of the plaintiffs and defendants whose behaviour had to be judged in court.

This approach is tied to the utilitarian understanding of individuals. In order to maximize utility, governors, from a utilitarian perspective, must know that an individual can choose and know that what they have chosen is ascertainable, and in some cases why. ${ }^{144}$ This 'empirical attitude' ${ }^{145}$ allows a putatively objective assessment of what goes on in the minds of others; ${ }^{146}$ Grote, for example, saw value in adopting psychological analyses. ${ }^{147}$ To put it bluntly, the 'root of the matter for classical utilitarians is that utility lies in internal mental states'. ${ }^{148}$ Without meaning to over-egg the

138. Steinway and Sons $v$ Henshaw (1888) 5 RPC 77, 80, Stirling J.

139. Great Tower Street Tea Company v Langford (1888) 5 RPC 66, 68, Stirling J.

140. (1890) 15 App Cas 251, 262.

141. Of course, this discussion is not to suggest that individuals did not have an internal life prior to the nineteenth century, merely that the law did not acknowledge it prior to that time. 142. [1932] AC 562.

143. George v Skivington (1869) LR 5 Ex 1.

144. John Stuart Mill, for example, speaks of individuals as 'free agents' and discusses the enforceability of contracts in terms of fraud, negligence and compulsion (three aspects that go to the justification of an action): Principles of Political Economy (Prometheus Books, Amherst 2004), 728-30.

145. G Scarre, Utilitarianism (Routledge, London 1996), 1.

146. One utilitarian, however, noted that the "largest and by far the most important part of all our speculations about mankind is based upon our experience of ourselves, and proceeds upon the supposition that the motives and principles of action of others are substantially the same as our own': J Stephen, Liberty, Equality, Fraternity (Liberty Fund, Indianapolis 1993), 205.

147. An Examination of the Utilitarian Philosophy (Thoemmes, Bristol 1990), Ch 12.

148. W Donner, The Liberal Self: John Stuart Mill's Moral and Political Philosophy (Cornell University Press, Ithaca 1991), 68. 
mixture, it is hard to imagine an assessment of confusion without first acknowledging the existence of an internal mental state.

With respect to the development of the mentality of defendants in the law generally, one of the first decisions in which there was a nuanced acknowledgement of the behaviour of the defendants is Longmeid v Holliday. In that case, Baron Parke used the phrase 'the exercise of ordinary care' in the discussion of what a defendant may be liable for. ${ }^{149}$ The court found for the defendant in that instance; however, the use of those words highlighted the possibility that behaviour was no longer to be assessed without concern to what could be seen to be normal behaviour. ${ }^{150}$ That is not to say that the courts of the 1850s considered that they could 'get inside' the heads of litigants. As already noted above, Page Wood VC held that it is 'impossible to look into the minds of the defendants or to detect their secret motives' ${ }^{151}$

Later that decade, it was held that a 'company might reasonably have anticipated that no mischief could occur, since no mischief had resulted ... for so long a period'. ${ }^{152}$ In this instance, no liability was found; however, the notion of 'reasonable' behaviour was extended, at least in the abstract, to a company. As a final example here, the defendant was held liable in Cann $v$ Wilson on the basis that they 'had no reasonable ground for stating the value to be $£ 3000$, and no reasonable ground for stating that the property could then be let for $£ 150$ ' ${ }^{153}$ In all these instances, the behaviour of the defendants was not assessed in terms of a simple 'yes/no' question; the courts, instead, adopted a more nuanced assessment of what the defendants could have done in the circumstances. In other words, the judges ruled on what the defendants should have considered before they acted.

Turning to the mentality of plaintiffs, the courts' acknowledged their 'internal life' in statements such as 'the buyer knows of the possible existence of the defects ... if he chose to purchase without a warranty ... he ought not be any better off for his ignorance'. ${ }^{154}$ The plaintiff was, in effect, held to a standard of reasonableness when entering into a sale:

[The plaintiff] may yet succeed by showing that he was misled by statements proved to be inconsistent with the truth couched in language capable of more than one interpretation, but as regards any such statements he is not entitled to say 'This must have been the meaning and this is false'; he must prove that he so understood it and relied on it as having that meaning. And his mere oath is insufficient; it must be a reasonable understanding. And, in considering what is reasonable, one must have regard to the particular person; his knowledge and means of knowledge of the matter at hand; and also his general experience and all other circumstances under which the question falls to be decided. ${ }^{155}$

The actual processes of reasoning were averred to in Arnison $v$ Smith: 'A person reading the prospectus looks at it as a whole, he sees good names attached to it, he observes

149. Longmeid v Holliday (1851) 6 Exch 761, 768, Parke B.

150. This approach is contrasted with the 'strict liability' approach that was more common before. An obvious example of this is the obligation that attached to common carriers - 'a carrier ... is responsible for any loss or damage arising in the course of the trust reposed in him, either from his own personal misconduct or that of his servants': Garnett $v$ Willan (1821) 5 B \& Ald 53, 60, Holroyd J. 151. Edelsten $v$ Vick (1853) 11 Hare 78, 85.

152. Cornman v Eastern Counties Railway Company (1859) 4 H \& N 781, 786, Bramwell B.

153. Cann $v$ Wilson (1888) 39 Ch D 39, 44, Chitty J.

154. Hill v Balls (1857) $2 \mathrm{H} \& \mathrm{~N} 299$, 306, Martin B.

155. Capel v Sim's Ships Composition Company (1888) 58 LT (NS) 807, 808-9, Kekewich J. 
other points which he thinks favourable, and on the whole he forms his conclusion' ${ }^{156}$ Such analysis of the behaviour of plaintiffs was not evident in eighteenth-century decisions. This is, in part, unsurprising, given the changes to the forms of action in the nineteenth century - the old forms, such as trespass, were focused on the "punishment and amends for past transgression' ${ }^{157}$ and, therefore, were not concerned with the behaviour of the person who suffered from the transgression.

With respect to trade mark law specifically, it may be noted that there is little by way of assessments of the mentality of consumers in the case law of the time - at least for most of the nineteenth century. To be clear, here the term 'consumers' denotes the abstract population of end-users of a product and not just the purchaser in a given contractual dispute. It is, again, unsurprising as the judges were, on the whole, adjudicating disputes between specific parties such as an identified vendor and an identified purchaser. That's not to say the law did not consider the impact of the behaviour of the defendants on consumers at all. As noted above, one provision of the 1883 Trade Marks Act was asserted to have been enacted for the benefit of the wider public. ${ }^{158}$ Before that, of course, judges did ask whether the public could be deceived, ${ }^{159}$ 'misled' ${ }^{160}$ or 'mistaken' ${ }^{161}$ - but these are, again, 'yes/no' questions and not an exploration of the 'mentality' of the consumers.

It was only in the two decades prior to the use of 'confusion' in trade mark cases that the internal life of consumers was considered. One of the first examples is from Singer Manufacturing Company $v$ Wilson: 'trade marks [are] made for those who have ordinary sight and ordinary minds, and not ... for persons of extraordinary acuteness or extraordinary dullness'. ${ }^{162}$ In another decision, Lord Esher referred to people with different levels of intelligence. ${ }^{163}$ Slightly earlier, Vice-Chancellor Bacon considered that a purchaser who made a mistake due to similar labels would be 'disappointed'. ${ }^{164} \mathrm{In}$ 1888, it was said that a 'connection between the name and the plaintiff's newspaper' may be 'establish[ed] in the mind of the public'. ${ }^{165}$ In Eno $v$ Dunn it was said that 'the public are constantly tempted to buy one thing when they think they are buying another'; ${ }^{166}$ and the Lord Chancellor referred to the 'ordinary person' who is faced with choice around products. ${ }^{167}$

That said, not all references to customers were to the detriment of the impugned business-holder. In 1879, Vice Chancellor Malins held that 'no rational person desiring to go into the Tavistock Street shop could have been misled when he

156. (1889) 41 Ch D 348, 369, Lord Halsbury LC.

157. JH Baker, An Introduction to English Legal History, 3rd edn (Butterworths, London 1990), 71.

158. Section 73.

159. For example, Edelsten v Edelsten (1863) 1 De G J \& S 185, 200, Westbury LC.

160. For example, Welch $v$ Knott (1857) 4 K \& J 747, 751; Hirst $v$ Denham (1872) LR 14 Eq 542, 550, Bacon VC.

161. For example, Hall v Barrows (1863) 4 De G J \& S 150, 159, Westbury LC; Lee v Haley (1869) LR 5 Ch App 155, 161, Giffard LJ.

162. [1876] 2 Ch D 434, 445, Jessel MR. Again, as noted above, the Master of the Rolls decided the case at first instance. None of the appeal judges used similar wording in their judgments.

163. In re Christiansen's Trade Mark (1886) 3 RPC 54, 62.

164. Hirst $v$ Denham (1872) LR $14 \mathrm{Eq} 542,554$. There was no nuance to the understanding of the purchaser - it was simply a 'tailor or other retail dealer' (at 553); that is, it was not the 'ordinary' or 'reasonable' tailor.

165. Licenced Victuallers' Newspaper Company v Bingham (1888) 38 Ch D 139, 143, Bowen LJ.

166. Eno v Dunn (1890) 15 App Cas 251, 263, Lord Macnaghten.

167. (1890) 15 App Cas 251, 255, Lord Halsbury LC. 
went into a shop opening into the Strand ... therefore, if Mrs Cellier was deceived it was her own fault'. ${ }^{168}$ Taken together, these statements show that the judges in the later nineteenth century were seeing consumers as more than mindless purchasers of goods - they had a mentality that was, in the end, capable of being confused. Admittedly, the evidence for utilitarianism is not thick on the ground in the case law; this, though, is not surprising as the judges are not asked to discuss matters of public policy - their task is merely to adjudicate the dispute between the parties before them. ${ }^{169}$

\subsection{Individuals as possessing (potentially wrong) knowledge}

The final condition of possibility for the introduction of confusion to be considered here builds on the understanding of individuals being seen as having an internal life-specifically, it is the growth of the idea, in law, that individuals can possess knowledge and, further, that that knowledge may be wrong. The role of knowledge may also be tangential in this discussion; however, it does tie in with the notion of the individual and with the apportionment of liability in the law. In terms of the understanding of knowledge in the wider culture, it is important to note both the broadening out of the education system in that century, ${ }^{170}$ the growing prominence of public libraries ${ }^{171}$ and the increasing profile, and value, of scientific research and invention in the public sphere. ${ }^{172}$ There is, of course, not the room to discuss these here in great depth. ${ }^{173}$

168. Civil Service Supply v Dean (1879) 13 Ch D 512, 516.

169. It may be noted, too, that an obvious place to look for statements with respect to public policy and utilitarianism would be in the Report of a Select Committee of the House of Commons. Unfortunately, the Report of the Select Committee on the Trade Marks Bill and Merchandize Marks Bill of 1862 consisted only of the Minutes of Evidence presented to the Committee with no discussion of that evidence. Of course, a number of those appearing before the Committee acknowledged the benefit to the public of trade marks (for example, Arthur Ryland, Select Committee on the Trade Marks Bill and Merchandize Marks Bill, Report, 1862, 41) but such comments cannot be taken to represent the perspective of the Committee itself.

170. It was in 1870 that 'universal compulsory education' came to England, with Russell noting that 'it would not have come then but for the Philosophical Radicals [the Benthamites]': B Russell, Freedom and Organisation 1814-1914 (George Allen \& Unwin, London 1934), 135. Of course, there was resistance. One 'High Tory' is quoted as saying, in 1827: 'As education has increased amidst people, infidelity, vice and crime have increased. At this moment the people are far more vicious and criminal, in proportion to their numbers, than they were when comparatively uneducated. The majority of criminals consist of those who have been "educated"': in H Perkin, The Origins of Modern English Society 1780-1880 (Routledge \& Kegan Paul, London 1969), 292-3. 171. Note, for example, the passing of the Public Libraries Act 1850. This Act facilitated the spread of libraries across the country. Unsurprisingly, utilitarians were key supporters of the public education; see generally, A Black, A New History of the English Public Library (Leicester University Press, London 1996); and M Battles, Library - An Unquiet History (W.W. Norton \& Co., New York 2003).

172. The profile of scientific advancement may be seen in the number of biographies of Sir Isaac Newton in the nineteenth century: R Higgitt, Recreating Newton: Newtonian Biography and the Making of Nineteenth-Century History of Science (Pickering \& Chatto, London 2007). The profile of inventors, in particular 'hero' inventors, is discussed in C Pettit, Patent Inventions: Intellectual Property and the Victorian Novel (Oxford University Press, Oxford 2004).

173. For a relatively recent survey of nineteenth-century science, see D Cahan (ed), From Natural Philosophy to the Sciences: Writing the History of Nineteenth-Century Science (University of Chicago Press, Chicago 2003). 
Casting the net widely, the nineteenth century saw, in other areas of law, an engagement with the importance both of knowledge generally and of specific forms of knowledge. For example, in a related field of intellectual property law, the courts began to consider the level of knowledge of the worker in the earlier incarnations of the conception of the 'person skilled in the art' in patent law. ${ }^{174}$ That area of law also acknowledged the potential for sharing protected knowledge with the early expressions around the 'research use exception' to the monopoly rights of a patent. ${ }^{175}$ In the employment context, the control of trade secrets became important. ${ }^{176}$ In defamation law, the defences of 'fair comment' ${ }^{177}$ and 'qualified privilege' were inventions of that century ${ }^{178}$ - with these defences facilitating the spread of information to those with an interest in it. ${ }^{179}$ More tangentially, it was in the second half of the nineteenth century that the common law doctrine of 'mistake' took form ${ }^{180}$ - a doctrine that required an acceptance of the importance of knowledge in the minds of the contracting parties and one that accepted that the knowledge possessed by an individual could be wrong. It was also in that century that the modern role of knowledge in the mens rea of criminal law took shape. ${ }^{181}$ Finally, the institution of law itself acknowledged the value of standardized knowledge with the creation of the Incorporated Council of Law Reporting, a body that, with the assistance of the General Council of the Bar, produced the authorized Law Reports. ${ }^{182}$

More specifically, there are two ways in which the role of knowledge is evident in the legal judgments around the use of trade marks and contracts more generally. First,

174. For example, a 'person of competent skill': Beard v Egerton (1849) 8 CB 165, 212, Wilde CJ. Further, a number of cases refer to 'scientific works' as being part of the prior art for assessing the novelty of an invention - such as Stead v Williams (1844) 7 Man \& G 818, 841, Tindal CJ.

175. Frearson v Loe (1876) 9 Ch D 48, 66-7, Jessel MR.

176. See, for example, Bryson $v$ Whitehead (1822) 1 Sim \& St 74, 77, Leach VC; Mallan v May (1843) 11 M \& W 653, 666, Parke B; and Leather Cloth v Lorsant (1869) LR 9 Eq 345, 354, James VC. See generally, C Fisk, Working Knowledge: Employee Innovation and the Rise of Corporate Intellectual Property 1800-1930 (University of North Carolina Press, Chapel Hill 2009).

177. 'Every man who publishes a book commits himself to the judgment of the public, and anyone may comment on his performance. If the commentator does not step aside from the work, or introduce fiction for the purpose of condemnation, he exercises a fair and legitimate right ... [and] does a great service to the public': Carr v Hood (1808) 1 Camp 355, 358, Lord Ellenborough.

178. In terms of the 'fair report' privilege - 'A fair account of what takes place in a Court of justice is privileged ... It is of great consequence that the public should know what takes place in Court': Davison v Duncan (1857) $7 \mathrm{El} \& \mathrm{Bl} 229,231$, Lord Campbell CJ. In terms of 'duty/interest' qualified privilege - 'In general, an action lies for the malicious publication of statements which are false in fact, and injurious to the character of another, and the law considers such publication as malicious, unless it is fairly made by a person in the discharge of some public or private duty, whether legal or moral, or in the conduct of his own affairs, in matters where his interest is concerned': Toogood v Spyring (1834) 1 C M \& R 181, 193, Parke B.

179. See generally, P Mitchell, The Making of the Modern Law of Defamation (Hart, Oxford 2005).

180. See C Macmillan, Mistakes in Contract Law (Hart, Oxford 2010).

181. Odujirin highlights the role of Austin in that process: A Odujirin, The Normative Basis of

Fault in Criminal Law (University of Toronto Press, Toronto 1998), Ch 7. For a discussion of the impact of Bentham's thought on the operation of the criminal law, see L Razinowicz, A History of English Criminal Law and its Administration from 1750: Volume 4, Grappling for Control (Stevens \& Sons, London 1968), Ch 6.

182. V Veeder, 'The English Reports, 1537-1865', in Select Essays in Anglo-American Legal History: Volume 2 (Little, Brown \& Co., Boston 1908), 154. 
chronologically speaking, there was the impact that the knowledge of the plaintiffs and defendants had on the apportionment of liability in disputes. Of course, the essence of fraud was that the seller of a good knew something that the seller did not - in Hill $v$ Gray, the contract was void because the vendor let the purchaser buy while under a misapprehension about the painting, ${ }^{183}$ and in Morley $v$ Attenborough the seller proceeded with the sale even though he knew he had no title to the chattel. ${ }^{184}$ Finally, from the 1881 decision of Arkwright $v$ Newbold: 'Supposing you state a thing partially, you make as false a statement as much as if you misstated it altogether. Every word may be true, but if you leave out something which qualifies it, you may make a false statement'. ${ }^{185}$ This is a more nuanced understanding of the issue of knowledge than existed earlier in the nineteenth century - evidence of a shift in the thinking of the judges that may be seen as contributing to the use of the term confusion in later trade mark decisions.

The next manner in which the conception of knowledge is found in the case law is linked to the utilitarian approach. That is, statements began to be made about the knowledge of consumers in the market. There are three ways in which the knowledge of potential consumers is considered. The first relates to those who operate as part of a trade. So, in Hutchinson v Guion, Willes J refers to a product that is 'well known in commerce'; ${ }^{186}$ in an 1867 decision, he also asked: "was there evidence that such knowledge was in the mind of the manager?'; ${ }^{187}$ and in Eno v Dunn, 'skilled chemists' who would have specific knowledge were referred to as potential customers. ${ }^{188}$ The second way considers consumers more generally. Lord Esher, for example, referred to people with different levels of education, ${ }^{189}$ and 'ignorant persons' were referred to in Singer Manufacturing Company $v$ Wilson. ${ }^{190}$ In one decision already referred to, the two categories of possible purchasers were contrasted:

The court does not protect the trade, who are well acquainted, or supposed to be well acquainted, with the various forms of instruments, but the public; and where, as in this case, a person who is not familiar with the details of the marks used by different manufacturers, but goes to buy a piano with some general notion that some foreign pianoforte makers have got a reputation ... and use a mark which has got externally something like a double $\mathrm{S}$ outside of it, I think that the defendant's combination is very much calculated to deceive. ${ }^{191}$

Here, the judge is saying that different levels of knowledge are expected of different categories of consumers and that incomplete knowledge is a key aspect of the test for the infringement of a trade mark. ${ }^{192}$ Finally, it is from the middle of the nineteenth century that judges speak about trade marks in terms of the marks as a sign of quality. Lord Chancellor Cottenham, for example, states that the 'mark of the manufacturer' of

183. (1816) 1 Stark 434.

184. (1849) 3 Ex 500.

185. Arkwright $v$ Newbold (1881) 17 Ch D 301, 318, James LJ.

186. (1858) 5 CB (NS) $149,163$.

187. Barwick v English Joint Stock Bank (1867) LR 2 Ex 259, 264.

188. (1890) 15 App Cas 251, 258, Lord Watson.

189. In re Christiansen's Trade Mark (1886) 3 RPC 54, 62.

190. [1876] 2 Ch D 434, 456, Mellish LJ.

191. Steinway and Sons v Henshaw (1888) 5 RPC 77, 80, Stirling J.

192. In the Canadian case already referred to, it was held that 'it is well known that illiterate people are often more instinctive in the practical knowledge they possess; and, in the purchase of articles of constant daily consumption, they are generally harder to deceive than their more intelligent and educated neighbours': Barsalou v Darling (1882) 9 SCR 677, 693. 
a piece of steel 'is the only indication to the eye of the customer of the quality of the article'. ${ }^{193}$ For customers to see marks as an indicator of quality requires that they: (a) have the capacity to know quality when they see it; and (b) may be misguided as to the quality of a product based on their knowledge of a mark.

It may be seen, therefore, that judges in the later nineteenth century saw knowledge as relevant in many contexts and, specifically, saw a role for it in the assessment of liability in trade mark disputes. The suggestion here is that a conception of 'confusion' requires at least an implicit acceptance of the fact that knowledge can be known - that knowledge may be an 'object' separable from the specific knowledge known by parties appearing in court. That is, if confusion is about a 'failure to distinguish' ${ }^{194}$ between different facts or concepts, then an idealized notion of accurate knowledge (as opposed to confused knowledge) is required. More fully, confusion, as a concept, relates to incomplete, imperfect or possibly false knowledge of something; it does not connote the certainty of a person who has been convinced of a false fact, instead it relates to the possibility that the person is wrong (as well as the possibility that the person is right). It is only after the courts accepted that individuals had interests that they could act upon (utilitarianism), that the individuals had a 'mentality', and that they possessed potentially erroneous knowledge as part of their inner life, that 'confusion' could be adopted as an external assessment of someone's state of being.

\section{CONCLUSION}

To sum up the argument, the use of the word 'confusion' in a discussion around the validity of a trade mark is not the result of random chance or a teleological progression of the jurisprudence in the area. That is, there was no 'need' for confusion to be introduced when it was; but, given the social and legal context, it is not surprising that it was used when it was. Returning to the conditions of possibility suggested here, the less moral judgment of confusion is not likely to have surfaced if the test for fraud still had a strong moral basis. The introduction of the registration system for trade marks required both a greater frequency of comparing marks and a greater need for a nuanced understanding of differences between marks. The shifts in the enforcement of contracts facilitated the greater appreciation of those who were outside the contract being adjudicated yet still impacted by aspects of the contract. More generally, the utilitarian threads in the law also supported an acknowledgement of the impact of marks on consumers; it was only after the law started to describe the 'inner life' of parties that there could be a legal conception of a mind to be confused; and finally, it required the acceptance of such an inner life for the courts to consider the capacity for individuals to possess knowledge and the potential for that knowledge to be incorrect.

193. Spottiswoode v Clarke (1846) $2 \mathrm{Ph} 154$, 157. In a slightly earlier decision, a similar perspective was intimated by the Lord Chancellor - 'for although there is no evidence to shew that the terms "Crowley" and "Crowley Millington" were merely technical terms, yet there is sufficient to shew that they were very generally used, in conversation at least, as descriptive of particular qualities of steel': Millington v Fox (1838) 3 My \& Cr 338, 352.

194. See $\mathrm{n} 7$ above. It may be noted that the Oxford English Dictionary cites the first use of the word 'confusion' in this sense as occurring in 1771. It is not surprising that it took a few decades, and the greater incorporation of the concept of knowledge, for it to enter into the legal discourse. 
Of course, a number of the conditions may be connected. For example, it may be that the utilitarian conception of the individual is a condition of possibility for the understanding of the mentality of parties in the law. It is also possible, however, that the changes in the economy in the nineteenth century meant that the judges' understanding of liability would have changed regardless of the shifts in the thinking of the political economists. ${ }^{195}$ It is, in part for this reason, not possible to say which, if any, of these conditions of possibility is the most important. It is also possible that there are other factors that contributed to the use of the term confusion. None of this explicitly argues against the assertion that the 'prevalence of the use of confusion rather than deception may be caused by a certain squeamishness on the part of claimants and judges to brand defendants as responsible for deception when there is no deliberate attempt to deceive'; ${ }^{196}$ it does, however, suggest that the story behind the use of the term 'confusion' is more complex than that.

The continued use of the term after its introduction is, of course, another matter one that is beyond the scope of this article. It could be that because the word was used by a Law Lord, in the early 1890s, then it had added value at a time when the House of Lords 'considered itself absolutely bound by its past decisions'. ${ }^{197}$ It could be that the use of the term enabled the divergence of actions for trade mark infringement from those for passing off (beyond the simple introduction of a statutory registration system for marks) - and this suited the socio-legal environment, and economy, of the twentieth century. Why the law developed the two forms of action, with the distinct tests for the gradations of objectionable conduct, is also outside the scope of this article. Instead, the research here has argued for the complexity of circumstances that allowed for the use of the term confusion; it is more than likely that the circumstances for the continued use of a new word or concept are similarly multiple and interconnected. ${ }^{198}$

195. See, for example, M Horwitz, Transformation of American Law, 1780-1860 (Harvard University Press, Cambridge 1977). For Horwitz, the legal change that came about was the result of shifts in the 'ownership' of the economic and political power during that time.

196. D Kitchin et al., Kerly's Law of Trade Marks and Trade Names, 14th edn (Sweet \& Maxwell, London 2005), $445 \mathrm{n}$ 81. It must be acknowledged that this statement was made in the context of actions for passing off and not trade marks; however, there is little other discussion, in the literature, around the introduction of the term into either area of law.

197. Cross and Harris, above n 51, 5.

198. One perspective is offered in C Dent and I Cook, 'Stare Decisis, Repetition and Understanding Common Law' (2007) 16 Griffith Law Review 131; however, that effort does not (nor did it intend to) offer a complete explanation as to why one phrase is chosen over another for repetition. 